\title{
Unions and Pension Reforms in Mexico: The Impact of Democratic Governance
}

\author{
Jean François Mayer and Patrik Marier \\ Department of Political Science \\ Concordia University \\ 1455 de Maisonneuve Blvd. West \\ Montreal, Quebec, Canada \\ H3G 1 M8 \\ (514) 848-2424, ext. 4073, 5187 \\ jmayer@vax2.concordia.ca \\ pmarier@alcor.concordia.ca
}

Prepared for Delivery at the Canadian Political Science Association Conference, Western University, London (Ontario), June 2-4 2005.

DRAFT: PLEASE DO NOT QUOTE WITHOUT THE AUTHORS' PERMISSION. COMMENTS ARE WELCOME! 


\section{Introduction}

In the fall of 2004, the Mexican Congress promulgated an important piece of legislation, which reformed the pension system of the employees of the Instituto Mexicano del Seguro Social (Mexican Institute of Social Security, IMSS). As a result of these changes, from August 2004 and on, new IMSS employees will be enrolled into a mandatory contributive private pension plan. This retirement benefits package is largely based upon the existing pension scheme for private sector workers, which stemmed from an extensive reform crafted in 1995 and which also targeted the IMSS. It is noteworthy that, in both cases of IMSS reform, Mexican labor unions were unsuccessful in their efforts to stop these processes of social security reform.

The behavior of the main union confederations in the context of the 1995 reform can be explained in great part by two main factors. Most importantly, the presence of a corporatist structure of interest intermediation, ${ }^{1}$ controlled by the Partido Revolucionary Institucional (Institutional Revolutionary Party, PRI) -the party which continuously led Mexico’s authoritarian regime from 1929 until the transitional elections of 2000significantly constrained the autonomy of the majority of Mexican labor organizations. During the PRI's 71 year rule, this institutional framework ultimately guaranteed the compliance of unions with governmental policy priorities (Bellin 2000; Berins Collier 1992; Burguess 1999; Grayson 1989; Murillo 2000). Nevertheless, electoral imperatives -resulting from the gradual political liberalization of the 1980s and 1990s, and related directly to the 1997 national legislative elections and the 2000 presidential electionsprompted the PRI-led federal government to accept some degree of compromising in the nature and scope of the 1995 reform. This was done in order to appease the labor organizations which opposed this project, by allowing those unions to claim some gains even if these were quite limited (Madrid 2003, pp. 83-86). These changes to the pension system of private sector workers were adopted by Congress in 1995 and implanted in early 1997.

The institutional environment of the 2004 pension reform differed markedly from that of the 1995 transformations. Perhaps most importantly, the PRI had lost power at the federal level as a result of the 2000 elections, which saw opposition candidate Vicente Fox of the Partido Acción Nacional (National Action Party, PAN) receiving a majority of votes, and thus obtaining the presidency. Among other things, this election represented the culmination of Mexico's process of transition to democracy, formally consecrating the end of the PRI-led authoritarian regime. This alternation of groups in power also resulted in the formal termination of the corporatist system which allowed for state control over labor organizations. Despite these significant transformations in the nature of Mexico's political regime as well as in the structure of labor's interest representation, unions were again unable to prevent or persuade Congress from approving the 2004 IMSS reform. Our paper seeks to explain this puzzling outcome.

\footnotetext{
${ }^{1}$ Our understanding of the term “corporatism” relies on Schmitter's (1974, pp. 93-94) influential definition: "a system of interest representation in which the constituent units are organized into a limited number of singular, compulsory, non-competitive, hierarchically organized, and functionally differentiated categories, recognized or licensed (if not created) by the state and granted a deliberate representational monopoly within their respective categories in exchange for observing certain controls on their selection of leaders and articulation of demands and supports”.
} 
The exploration of this research question draws its significance from several factors. First, given the success of the government and its allies in Congress in passing these transformations to the IMSS functioning, it is likely that future reforms of Mexico's remaining public pension system would adopt a similar shape, in which case it becomes particularly important to analyze and understand the strategies utilized by each major actors in order to defend and promote their interests during this process. Second, the 2004 pension reform is telling of persistent divisions between Mexico's major union confederations inherited from the authoritarian regime, which affect negatively labor organizations' capabilities to mobilize their membership as well as sway public opinion under the new democratic regime. Third, several union leaders as well as political analysts considered the 2004 pension reform to be a frontal attack on independent unionism, a claim that demands corroboration (Méndez 2004, 20 June; MLNA 2004, July). Finally, our study seeks to test an assumption that is central to the existing literature on pension reform in Latin America, according to which important reforms are less likely to occur under democratic regimes than under authoritarian rule.

The paper is divided into four sections. First, we briefly review the literature addressing the impact of political regime types as well as of the corporatist mode of interest representation on the behavior and mobilization capabilities of labor organizations. We emphasize the effect of those constraints on patterns of exchanges and linkages of power between the state and unions, particularly in cases of restructuring of pension schemes in Latin America during the 1980s and 1990s. Second, we examine the main elements of the 1995 and 2004 pension reforms in Mexico, as well as their impact on the workers' contributive responsibility and retirement conditions. Third, we compare and contrast the strategies, discourse, and behavior of unions as well as of the government and the main parties in the Mexican Congress in the context of the 1995 and 2004 pension reforms. Finally, we point at the theoretical implications of our findings for the existing body of research dealing with the issue of pension reform in Latin America, and we suggest future avenues for research.

\section{Institutional Configurations, Unions, and Pension Reforms in Latin America}

Various strands of the literature have underlined that the low levels of democracy often found in Latin American countries during the 1980s -and to a lesser extent during the 1990s-have often facilitated the passing of unpopular socioeconomic measures. This is due, among other things, to the fact that populations typically feared stark reprisals from authoritarian governments if citizens dared organizing to oppose publicly such measures. Furthermore, non- or semi-democratic regimes were often characterized as being more likely to fulfill their loan commitments with international financial institutions than democratic governments (Haggard 1992; Haggard and Kaufman 1992, 1995; Kaufman 1985; Kaufman and Stallings 1989).

There is strong support for this argument in the field of pension reform studies. In particular, a nine country study conducted by Mesa-Lago and Müller (2002) concluded that the degree of democratization of a Latin American country -as measured according to the Freedom House index-is the most important variable in explaining the degree of 
privatization of new pension systems. ${ }^{2}$ Perhaps the most famous case of pension reform in Latin America occurred in Chile during the years 1980-1981, while the country was under the rule of Gen. Augusto Pinochet. Under the guidance of its economic team dubbed the "Chicago Boys"- the Chilean authoritarian government enacted a pension reform that abolished the public system in favor of a fully private one, leaving the state acting as a last resort to ensure a minimum income to the poorest of workers. Popular resistance to this project was minimal, due in great part to the repressive nature of the regime in place, which dissuaded the citizenry from mobilizing against the reform. Furthermore, Pinochet's economic team had little difficulties ignoring the criticism stemming from other circles within the country's administration (Acuña \& Iglesias 2001; Borzutzky 1998).

Mesa-Lago and Müller's analysis also deals with the 1995 restructuring of Mexico's pension scheme. Strongly influenced by the Chilean reform, these transformations appear to have been made possible in great part by the authoritarian nature of the Mexican regime at that time. Indeed, despite the gradual liberalization of the country's political regime during the 1980s and 1990s -observable in particular in the emergence of electoral competition and the subsequently increasing strength of the opposition - the PRI retained a firm grip on political power until 2000. According to this literature, this context allowed for the relatively swift adoption of the proposed pension reform, and its relatively unproblematic implementation in 1997 (Huber and Stephens 2000, p. 9; Mesa-Lago and Müller 2002, pp. 698-9).

Aside for regime type, this body of research indicates that another institutional factor played a role of central importance in explaining the particulars of organized labor's behavior towards socioeconomic restructuring in general, and pension reform in particular, in Mexico: the corporatist arrangement of state-labor relations. In essence, corporatism limits associational and organizational autonomy through the accreditation of a small number of constituent units -the "corporations" - which participate in a formally institutionalized relation with the state (Heredia 2001, pp. 3-4). As mentioned above, the PRI had established a corporatist system of interest intermediation during the 1930s, which, among other things, granted party leaders a high degree of control over the socioeconomic demands and political activities of the great majority of unions (Middlebrook 1995, p. 141, 148-153). This system was key in insuring the stability and continuity of the PRI-led authoritarian regime, as it regulated and limited access by social actors to Mexico's decision making apparatus (Berins Collier 1992, p. 11; Patroni 2001, pp. 255-257; Zapata 1995, p. 49).

Two categories of worker organizations resulted from this configuration of statelabor relations. Unions affiliated to the PRI through the corporatist framework are generally labeled “official labor unions” (OLU). In exchange for their compliance with the broad policy orientations of successive federal governments during the PRI's authoritarian rule, members of these corporatist unions were granted a variety of socioeconomic benefits, as well as preferential political representation for the leaders of these groups. Official labor organizations were -and still are-affiliated to a union confederation called the Congreso del Trabajo (Labor Congress, CT), which represents

\footnotetext{
${ }^{2}$ The nine country studied are Chile, Peru, Columbia, Argentina, Uruguay, Bolivia, Mexico, El Salvador, and Costa Rica. Only Bolivia escaped this relationship. Despite having introduced the most private elements in its pension system, it ranked third in terms of its degree of democratization.
} 
roughly 6 million workers (Grayson 1989, pp. 19-32; Caulfield 1998, p. 7). The CT was still linked to the PRI in 2004, and that party still exerted substantial influence over the Labor Congress' leadership.

The second category of labor organizations - generally known as “independent labor unions” (ILU)—resisted the constraints put by corporatism on union organization and interest representation, and rejected state infringement on workers rights and freedoms (Grayson 1989, pp. 33-42; De la Garza 1991, p. 153-156). Relations between the successive PRI-led federal governments and independent unions were hence quite difficult, from the time the PRI consolidated its corporatist network in the 1940s until the moment it relinquished power in 2000. In fact, ILU were typically marginalized from the country's main political dynamics, since these groups' demands for enhanced democracy in internal union procedures and in state-labor relations were considered by the PRI's leadership as a direct threat to the very existence and continuity of the party's corporatist system, as well as of the authoritarian regime this framework underpinned (Alcalde 2003, pp. 25-27; Santos Azuela 1989, pp. 39-42; De la Garza 1998, pp. 198-200; Patroni 1998, p. 114). The great majority of these independent labor organizations are comprised by the Unión Nacional de Trabajadores (National Workers' Union, UNT), the main federation of independent unions, and the Frente Sindical Mexicano (Mexican Union Front, FSM), representing approximately 1.5 million workers.

The transitional elections of 2000 resulted in the replacement of the PRI at the country's presidency by PAN candidate Vicente Fox. In addition, this event heralded the formal end of the corporatist dynamics that had characterized patterns of exchanges and linkages of power between the state and unions until then. ${ }^{3}$ Indeed, although the great majority of official unions remained attached to the PRI after the transition -through their membership in the Labor Congress - that party lost its unhampered access to the state apparatus and its resources, which were necessary to the maintenance of the corporatist system it headed. As such, the PRI could no longer utilize various financial and political incentives, as well as the threat and use of coercion, to persuade OLU to collaborate, while marginalizing politically the reticent ILU. ${ }^{4}$ Nevertheless, is should be noted that the legal framework regulating state-labor relations has not been modified since the regime transition of 2000, and still carries provisions allowing for multiple forms of nondemocratic state control over organized labor (Mayer 2005). For instance, the state still may directly restrict the conditions of union registration, reject the composition of unions' executive committees, as well as curb labor organizations' right to strike.

Findings of the existing literature lead us to suppose that Mexico's regime transition to democracy in 2000 as well as the formal termination of the corporatist system would reduce the likelihood of the new federal government and the Congress embarking on a significant reform of the public pension system, and would favor the emergence of a strong movement of resistance among labor organizations if such project were to arise. In fact, contrary to this expectation, Congress enacted an important

\footnotetext{
${ }^{3}$ It should be noted that the PRI's corporatist framework had begun to deteriorate during the 1980s and 1990s, although it still proved to be an efficient instrument of labor control by the state during that period of time (Teichman 1996; Burgess 1999; Murillo 2000).

${ }^{4}$ Although corporatism was formally terminated in 2000, we retain the label "OLU" when referring to CTaffiliated labour organizations in this paper, for the sake of simplicity and conciseness. The term "exofficial unions" is also utilized interchangeably at times.
} 
modification to the IMSS' functioning in 2004, which unions were unable or unwilling to prevent. The following pages seek to clarify this contradiction between the existing literature's assumptions and the actual patterns of labor mobilization as well as unions' discourses during the 2004 process of pension reform. We begin our analysis by presenting an overview of Mexico's pension system, in order to underline the importance of the 1995 and 2004 reforms for labor organizations. We then turn to a comparative analysis of the discourse and behavior of the main actors involved in this process.

\section{A Comparison of the 1995 and 2004 Pension Reforms}

Like most continental European and Latin American countries, the Mexican pension system is strongly fragmented along occupational lines resulting in divergent rates of coverage and benefits. Governmental employees at the national and state levels as well as teachers receive benefits from the Instituto de Seguridad y Servicio Social de los Trabajadores del Estado (Institute for the Social Security and Services of State Workers, ISSSTE), or special schemes set up by regional authorities. Oil workers and members of the National Defense and of the Navy each participated in exclusive pension funds. For their part, up until the reform of 1995, the majority of workers active in the private sector contributed to and received their retirement benefits from the pension system of the IMSS.

Since its creation in 1943, the IMSS has provided coverage in three distinct areas, in addition to administering a pension fund. These areas are: work-related injuries, health care (sickness and maternity), and child care centers (Espinosa-Vega \& Sinha 2000, p. 2). The IMSS' area of activity which concerned pensions also included the provision of coverage for disability, loss of job (severance), and life insurance. This area is generally referred to by its Spanish acronym of "IVCM", which stands for Invalidez, Vejez, Cesantía y Muerte. By 1995, the IMSS received contributions from roughly 10 million workers, which then represented the equivalent of 33\% of Mexico's work force. The Institute provided its coverage to 34.3 million people, roughly $37.7 \%$ of the total population of the country at that time (INEGI 2005). ${ }^{5}$ The IMSS' funding for its pension scheme was based on a pay-as-you-go scheme, to which workers, their employers, as well as the state contributed. This contribution represented the equivalent of $8.5 \%$ of workers' salaries. Of this number, workers paid $70 \%$, employers $25 \%$, and the state $5 \%$ (Arvizu Treviño 2002, p. 5; Reyes Frausto 2000, p. 84).

In 1995, the federal government of Ernesto Zedillo enacted a significant reform of the IMSS' pension system, which became effective on 1 July 1997. Many imperatives led to the creation and adoption of this reform. First, and perhaps more importantly, the IMSS had since its creation utilized the moneys accumulated from the aforementioned tripartite worker-employer-state contributions to compensate for recurring deficits in the health and maternity programs. Internal studies estimated that the IMSS would start running a deficit by 2004. Projections for subsequent years indicated that by year 2010, the Institute would hold a debt of $\$ 2.3$ billion US -a figure that would double every year until 2030, by which time it would represent more than $10.5 \%$ of Mexico’s GDP (IMSS

\footnotetext{
${ }^{5}$ The IMSS offers services such as health care to affiliated workers as well as their families. The "IMSSSolidarity" program also offered basic coverage to another 10.5 million destitute Mexicans, for a total IMSS coverage accounting for 49.3\% of Mexico's population (Reyes Frausto 2000, p. 81).
} 
2001). Second, the high rates of inflation which affected the country during the 1980s and 1990s impacted negatively the real value of pension payments (Cerda 1996, p. 2).

Third, many employers and workers in the formal sector adopted an "exit strategy" by discontinuing their contribution to the regime after a certain period of time. Indeed, the dissociation between high levels of contributions and low levels of benefits led many workers to participate in the program only until they reached the minimum mandatory number of weeks of contributions - set at 500, under the old system-in order to receive benefits. Once this threshold was attained, the benefits incurred as a result of continued contributions over a long period of time increased only marginally. Indeed, the IMSS' regular pension system is calculated as a function of Mexico's minimum salary, which was approximately \$1.7 US per day for 1995 (INEGI 2005). Therefore, retiring workers who typically earned minimum wages would receive a monthly pension of roughly \$40 US. These monthly pensions varied little as a factor of increased contribution during the workers’ active life. For instance, in 1995, workers who earned ten times the minimum salary would receive a monthly pension of only up to \$64, even if they earned the equivalent of this salary (in constant dollar) and contributed to the IMSS regime for 30 years (Espinosa-Vega and Sinha 2000, p. 3). Consequently, after attaining the mandatory minimum of 500 weeks of contributions, many workers elected to escape the heavy salary deductions supposed by their participation in the IMSS' system, either by continuing their work in an unofficial fashion -i.e. without appearing on their employers' list of workers - or by joining the informal sector. Similarly, business owners often failed to declare the real number of workers they employed, in order to reduce their contribution to the IMSS (Cerda 1996, pp. 2-3).

As a result of these significant structural problems, it appeared by the early 1990s that the public pension system administered by the IMSS was in need of a profound transformation, as the payments it offered were typically inadequate to ensure decent minimal living standards to its beneficiaries. This situation promised to only worsen in the future if nothing was done to modify it. The 1995 reform crafted by Ernesto Zedillo's government essentially sought to transform the IMSS' pension system from the previous pay-as-you-go arrangement to a model characterized by individual retirement accounts and a minimum pension guaranteed by the government, and administered by the private sector -generally divisions of existing financial institutions (Arvizu Treviño 2002, p. 5). These private administrators, labeled Administradores de Fondos de Ahorro (investment management companies, AFORES), were authorized by the government to impose "reasonable" management fees to their clients, and were supervised and regulated in their work by a governmental agency: the National Commission for the Saving System for Retirement (Comisión Nacional del Sistema del Ahorro para el Retiro, CONSAR).

Under the new system, the aforementioned contributions of $8.5 \%$ of workers salaries to the previous IMSS pension plan was separated in two sections: $4.5 \%$ are solely devoted to the new private pension scheme, while the remaining $4 \%$ is still collected by IMSS in order to fund the Institute's survivorship, health care and disability programs for pensioners -the rest of the original IVCM area. Since 1995, employers have also had to supply an extra $2 \%$ to the new individual pension accounts. In the case of workers earning minimum wages, the state contributes an additional $5.5 \%$ of the official minimum salary -a payment labeled "social contribution”- to these individuals' pension funds (Carstens 1997, p. 154). Previous thresholds on the minimum number of weeks necessary 
to qualify for a pension were abolished. In doing so, the government hoped that private sector workers would see their pension contributions as an investment in their own future -therefore augmenting the incentives for their sustained participation in the new scheme (Cerda 1996, p. 2). The implementation of the reform also supposed that all private sector workers contributing to the IMSS' pension fund would gradually shift to the AFORES of their choice within a few months, at the latest.

By 2004, the IMSS counted more than 45 million beneficiaries (43.7\% of Mexico's total population), with 12 million private sector workers (28.6\% of the Mexican work force) and 800,000 businesses contributing to the Institute's health, maternity, disability, and childcare programs. There were roughly 370,000 unionized employees at the service of the Institute (not counting administrators, temporary workers and “consultants”, who numbered approximately 40,000), and 120,000 retired IMSS workers (IMSS 2004, p. 228; Reforma 2003).

The financial health of the IMSS had become precarious since 1995. Indeed, Governmental reports as well as IMSS internal documents indicated that this was due in great part to the generous pension scheme enjoyed by the very employees of the Institute (IMSS 2003; IMSS 2004, pp. iii-iv). Retired IMSS employees numbered 120,000 by the end of 2004. In a nutshell, before the 2004 reform, IMSS workers could retire after completing 28 years of services (or 27 years, in the case of female employees), which set the average retirement age of IMSS workers at 53. By comparison, Mexico's official retirement age is 65, although individuals may retire after completing 40 years of work. The pension benefits of retired IMSS employees represented $130 \%$ of their last salary. Pensions were also indexed when the salaries of active workers were increased. Furthermore, retired IMSS employees received the regular (and much less considerable) pension paid by the Institute to affiliated individuals. As a result, retired IMSS workers received an average monthly pension of \$1500 US in 2004. As a point of reference, retiring private sector workers who earned the same salary as IMSS workers at the moment of their retirement, would only receive \$210 US per month in pension (IMSS 2004, p. 122).

Another significant problem with the existing IMSS worker pension scheme resides in the Institute's practice of utilizing the contributions of the 12 million private sector workers and their 800,000 employers affiliated to the Institute and benefiting from its life, health care and disability programs, in order to cover the expenses resulting from the payment of pensions to retired IMSS workers. For instance, according to an IMSS internal analysis presented to the Mexican Congress in 2004, the Institute paid \$1.83 billion US in pension and health care expenses for IMSS retirees in 2003. Of this amount, the contributions of IMSS workers represented only \$138.6 million US, and the moneys supplied by the federal government in its quality of employer represented $\$ 380$ million US (IMSS 2004, p. 123). In order to compensate for this gap between paid pension benefits to retired IMSS workers and the contributions received from the federal government as well as IMSS workers, the Institute resorted to utilizing \$1.31 billion US from the worker-employer contributions of the private sector workers and employers affiliated to the Institute, which were originally destined to be invested in the IMSS' infrastructure and various programs. This represents roughly $9 \%$ of the total workeremployer contributions for 2003. As a result of this situation, among other things, the IMSS has accumulated a debt estimated at \$35 billion US in 2004, in order, it argued, to 
sustain its functioning and services to its beneficiaries. Costs for the IMSS retirees in 2004 were evaluated at \$2.1 billion US, which the Institute expected to fund in great part by drawing \$1.6 US billion from the worker-employer contributions, roughly $10.5 \%$ of total payments (IMSS 2004, pp. 123-4, 138, 220).

It is in this context that a reform project was introduced to Congress on 14 July 2004 by the PRI. This proposal made it mandatory for new IMSS workers to contribute to a new pension fund, managed by the Institute, which can be used only for the purpose of providing retirement benefits for these new workers. Furthermore, the reform made it illegal for the IMSS to utilize the contributions of the affiliated private sector workers and their employers, as well as to utilize its reserves, in order to pay for the specific pensions and benefits of these new IMSS employees (Beltrones Rivera 2004). The reform hence created two categories of workers. Those employees already in place would remain under the previous retirement and social advantages plan, while the new workers' benefits would be much less considerable. Under the new scheme, workers will pay at least $10 \%$ of their salary (instead of the 3\% they previously paid) in contribution to their pension fund, they will retire after 35 years of service (instead of 27 or 28), and will receive 100\% (instead of 130\%) of the value of their last monthly salary in pension payments (MLNA 2004, August).

The 2004 reform proposal was adopted by the Chamber of Deputies only two weeks after its introduction -a particularly rapid pace for the adoption of a new piece of legislation in Mexico. The congressional fractions of the PRI, which held a simple majority of seats in both Houses of the Mexican parliament, and the PAN, which constituted the second party in importance, were the main proponents of this project. As well, Congresspersons of the minority parties PVEM (the Green Party of Mexico) and Convergencia por la Democracia (Convergence for Democracy, a centrist party) voted in favor of the reform. Members of the third force in Congress, the center-left Partido de la Revolución Democratica (Party of the Democratic Revolution, PRD), opposed the reform project, joined in their action by the small Congressional delegation of the leftist Partido del Trabajo (Labor Party, PT) (Guerrero et al. 2004). The Mexican Senate approved the reform a week later, each party adopting the same position in the Upper House as it did in the Lower House of Congress (Becerril 2004; Salazar et al. 2004). ${ }^{6}$ The reform project also received the backing of President Fox’ administration.

\section{Variations in Attitudes and Behavior of Unions towards Pension Reforms in Mexico}

The comparative examination of union strategies during the 1995 and 2004 pension reforms reveals significant similarities as well as differences in the patterns of mobilization and the nature of discourses utilized. In fact, whereas the literature suggests that the adoption and implementation of the 1995 pension reform was due in great part to the authoritarian and corporatist nature of Mexico's political system, the dynamics surrounding the 2004 reform indicates that other explanatory elements were at play. In particular, it seems that the 2004 reform was successfully promulgated due mainly to the division between independent and (by then) ex-official unions; to the organizational weakness and lack of political will of ILU; and to the ability of the government and the

\footnotetext{
${ }^{6}$ After the July 2003 elections, the PRI held 223 seats out of 500 in the Chamber of Deputies, the PAN 150, the PRD 97, the PVEM 17, the PT 6, Convergencia 5. In the Senate, the PRI held 60 seats out of 128, the PAN 46, the PRD 16, and the PVEM 5 (Cámara de Diputados 2005; Senado de la República 2005).
} 
PRI -which held a simple majority in both Houses of Congress - to successfully promote their discourse so that it eventually prevailed over that of independent unions in the eyes of the citizenry. In that context, the type of regime in place, as well as the formal termination of the authoritarian regime's corporatist arrangement, seem to have had a relatively negligible impact on the processes surrounding the adoption of the 2004 reform.

\section{The 1995 Pension Restructuring}

In 1995, the Sindicato Nacional de los Trabajadores del Seguro Social (the National Union of Workers of the Social Security, SNTSS) counted on a membership of 300,000 workers, making it one of Mexico's largest unions. The SNTSS then belonged to the Labor Congress and was hence affiliated to the PRI, which was still in power at the time. Even though several independent unions existed in 1995, these had been hard hit by over a decade of harsh economic adjustment and restructuring policies, which left them relatively disorganized and demobilized (De la Garza 1994, 1998). Furthermore, as mentioned above, PRI federal governments had been rather successful at marginalizing these labor organizations from the country's political process.

Existing studies indicate that, when the government of Ernesto Zedillo announced its pension reform project in the spring of 1995, the SNTSS, a few official and independent unions, and the IMSS' administrators expressed their opposition to the proposed transformations. Although it too disapproved of the reform proposal as originally set forth, the CT's leadership accepted to participate in tripartite corporatist negotiations called by the Zedillo government, which also included representatives of the state and of the business community. These talks yielded a new reform project in the fall of 1995, which benefited from the support of these three actors (Mesa-Lago \& Müller 2002, p. 697-9). This new version of the reform was considered by the leaders of the Labor Congress as generally positive for their interests. Indeed, the Zedillo government allowed for the continuation of employers' contribution to the health care fund administered by the IMSS, as well as collection by the Institute of the workers' contribution to the state-ran housing fund (the INFONAVIT). The exclusion of the INFONAVIT from the reform was of particular importance to the official unions' leadership since these unions' executive committees had traditionally been in control of the fund's functioning, which they utilized as a significant source of patronage (Murillo 2001, pp. 103-4). In return for these concessions to the demands of CT leaders, the PRI federal government demanded -and obtained - the full support of official labor organizations to its reform project (Madrid 2003, p. 85-6).

Although the CT had managed to extract some concessions from the government, these compromises did not satisfy the SNTSS, since the heart of the reform -the privatization of the private workers' pension scheme-remained intact in the end. As such, the Institute lost the exclusive right to administer the private sector's pension fund. This constituted an important defeat not only for the IMSS but also for its union, which was represented on the Institute's pension fund administration committee (Murillo 2001, p. 103). Furthermore, the SNTSS claimed that this reform represented the beginning of the all-out privatization of Mexico's pension schemes -which included those ran by the ISSSTE, PEMEX, the Navy, and the Army. The PRI government was however very careful not to include these pension plans in its proposed reform, in order to prevent the 
mobilization of the powerful public sector union against it (Madrid 2003, p. 84). This scenario would have likely shifted the balance of power between the government and opponents to the proposed changes to the IMSS' pension system, making the reform's success much more doubtful.

The SNTSS and its allied unions carried out marches and demonstrations during the negotiation process, but did not resort to strikes. This is attributable to several factors. First, the pro-governmental position of the CT's leadership impeded the building of a strong and unified union coalition in opposition to the reform project. Second, the PRI government of Zedillo put tremendous pressures on rebellious unions and granted them very little leeway for expressing their dissent (Mesa-Lago \& Müller 2002, p. 698-699). Furthermore, the above-mentioned configuration of the Mexican Federal Labor Law granted the state control over labor tribunals, which allowed the PRI federal government to dismiss as being illegal any effort by the SNTSS to stage a strike, and possibly repress the union and its members.

The perceived lack of responsiveness on the part of the PRI as well as the generalized absence of support from fellow CT-affiliated unions to their demands, deeply disappointed the leaders and membership of the SNTSS. In November 1997, a few months after the reform was officially implemented, the SNTSS left the CT and joined 110 independent unions which organized under the umbrella of a new labor confederation: the National Workers' Union (UNT). The successive Secretary-Generals of the SNTSS have since then also been members of the tripartite presidency of the UNT (Burgess 2003, p. 95; Mayer 2005).

\section{The 2004 Pension Reform}

The 2004 project of IMSS reform was officially introduced to the Lower House of Congress by PRI deputies, who affirmed that the CT leadership was its original author (Nuñez 2004a). It is likely that this reform was part of a series of projects set forth by the PRI, which sought thusly to flex its political muscle and show the Mexican citizenry that it could "govern from Congress" -in stark contrast with the Fox administration, which had repeatedly failed in its attempts to further its reformist policy agenda. As mentioned above, the PRI's project received the backing of the PAN, the PVEM and Convergencia. The federal government of Vicente Fox also offered its support to the reform, as did the CT and, this time, the IMSS' administrators (Cevallos 2004, p.1). Opposition to the reform project mainly came from the PRD and the PT, from the SNTSS and its allies of the two main independent union confederations -the UNT and the FSM-, as well as from social movements such as El Barzón and El Campo No Aguanta Mas (debtor and peasant organizations).

The 2004 changes to the IMSS' functioning were cast in a much different light than the 1995 pension restructuring. As a prelude to the reform, the IMSS made public its annual Financial Report by early summer 2004. This Report identified three main challenges for the Institute, the most important one being the "increasing obligations derived from the Pension and Retirement Regime (RJP), as well as the collective labor contract that the Institute [...] has signed with the [...] SNTSS” (IMSS 2004, p. iii). According to the IMSS' administrators, the existing pension scheme of IMSS workers had forced the Institute to devote 10 \$US billion to this retirement package between 1994 and 2003, whereas for the same period it only invested 2.7 \$US billion in medical 
services and infrastructure. As mentioned in the previous section, the Institute affirmed that it had to channel $9 \%$ of the contributions of its affiliated 12 million private sector workers and their 800,000 employers in order to meet its contractual obligations with its own workers for the year 2003 only, and that matters would become increasingly worst as time passed.

This report set the tone for subsequent debates surrounding the reform process. Hence, whereas the 1995 reform was presented by the PRI-led federal government as being necessary to ensure Mexican private sector workers a decent and steady income during their retirement, the 2004 reform would typically be portrayed by its proponents as a question of socioeconomic equity and justice. Indeed, the discourse of the 2004 reform supporters advocated the removal of obstacles diminishing the scope and efficiency of services provided by the IMSS to its beneficiaries, and threatening the Institute's very sustainability. In fact, the focus of the 2004 pension reform was much narrower than that of its 1995 predecessor, as it targeted specifically the IMSS workers' retirement package. Therefore, the project potentially affected the interests of 375,000 workers and 120,000 retirees, by comparison with the 10 million workers impacted by the 1995 reform.

Proponents insisted that the exiting configuration of the pension plan of the Institute's workers was penalizing its 45 million beneficiaries, by diverting the IMSS' financial resources away from their rightful objectives of health care provision (Beltrones Rivera 2004; Reforma 2004a; Orihuela and Selene Pérez 2004). Supporters of the reform thus claimed that the principal objective of these changes was to stop the hemorrhage of IMSS financial resources and to make sure that the Institute would utilize properly the moneys it received from the worker-employer contributions as well as from the state. Among other things, reform proponents indicated that those moneys should be invested in infrastructure and in the provision of enhanced care to the 45 million individuals who make use of the IMSS' services every year. Proponents added that pension and benefits of existing workers and retirees of the IMSS would not be touched by the reform. Nevertheless, new workers would be affected by the transformations, which would allow the Institute to eventually return to a position of solvability (Mendez 2004).

The discourse of the reform's supporters squarely placed the blame on the Institute's employees and their retirement package for the IMSS' financial troubles, and in particular, for the Institute's inability to invest adequately in its physical plant and for the deterioration of its care-giving capabilities. This message was conveyed through radio and TV publicities, which often attacked SNTSS members and their leader, Roberto Vega Galina, who were accused of enjoying privileged socioeconomic benefits to the detriment of the poor (MLNA 2004, April).

Opposition groups, led by the SNTSS and its independent union allies, adopted of course a much different line of argumentation, comprised of a few interrelated main elements. First, they insisted that the proposed pension reform was illegal, as the working and retirement conditions of the IMSS' employees were detailed in the collective contract tying them to the Institute, as well as in the Constitution. ${ }^{7}$ Opponents affirmed that the reform would essentially short-circuit the collective contract renegotiation taking place at the time between the IMSS and the SNTSS, and that this would constitute a patent

\footnotetext{
${ }^{7}$ Constitutional Article 123 contains provisions which, among other things, regulated the creation of the IMSS and its sectors of activities, as well as detail the financial responsibilities of the Institute towards its employees.
} 
infringement on the IMSS workers' constitutionally guaranteed labor rights and of the IMSS' financial obligations towards them (Alcalde Justiniani 2004; Nuñez 2004b).

Secondly, independent unions claimed that the proposed reform represented a massive attack on the independent labor movement in general, and on the SNTSS specifically (MLNA 2004, July). In fact, Roberto Vega Galina, the SNTSS' Secretary General, blamed the Fox government for allowing Congress to intervene in collective contract negotiations between the IMSS and its union so as to break the power of the SNTSS and reduce significantly the benefits of the Institute's workers. In order to do so, Vega Galina explained, the government and the Congress ignored the Federal Labor Law and violated the Constitution (Personal interview, August 2004). Other representatives of the opposition forces to the 2004 reform considered that this attack on independent unions was most likely due to their rejection of, and resistance to, the government's economic policies, and in particular its plan to privatize the remaining state industries present in the energy sector of the economy (Personal interview with Agustin Rodriguez, co-president of the UNT and federal Deputy for the PRD, August 2004).

Finally, the SNTSS and its independent labor allies claimed that the proposed pension changes was particularly insidious, as it represented an initial step in the process of privatizing the remaining public pension schemes -and in particular the one administered by the ISSSTE. Indeed, independent union leaders and their allies argued that the problems of the IMSS came from the poor management of the Institute by its administrators, as well as the overly high salaries commended by the 40,000 external consultants [empleados de confianza] they "illegally contracted" (Reforma 2004a). They added that the PRI, the PAN, the CT and their allies were therefore misleading the population by blaming the SNTSS and its members for the financial troubles of the Institute. The leaders of the UNT claimed that the SNTSS workers should not be penalized for benefits that they had acquired over time and through important struggles opposing it to the IMSS' administrators and the state during several decades. Secretary General Vega Galina insisted that, if anything, the collective contracts and benefits of IMSS workers should serve as a point of reference and as a goal for other workers, not as something shameful (MLNA 2004, April).

According to independent union leaders, the PRI and the Fox government were in fact trying to hide the true goals of this pension reform: the gradual privatization of all of the IMSS' activities, the destruction of the SNTSS, and preparing the eventual privatization of all public pension schemes (UNT 2004). In order to give added political weight to their line of argumentation, the SNTSS and its allies threatened to stage a general strike in order to oppose the adoption and implementation of the project.

Although independent unions could count on the PRD's support in Congress, that party did not hold sufficient political weight to single-handedly stop the reform process. Coordination between the party's actions and those of the independent unions also proved problematic and conflict-ridden (Interview with PRD Local Deputy Alejandra Barrales, 23 August 2004). As such, the SNTSS and its allies did not attain their goals during the 2004 pension reform process. Indeed, the SNTSS and the independent labor organizations were unsuccessful at extracting any significant compromises from the government, as the PRI, the PAN and the Fox government refused to accede to their demands and adopted the proposed reform in its integrality. 


\section{Discussion of Findings}

The results of this research suggest that three main causal elements contributed significantly to the failure of the SNTSS and its independent labor allies' efforts to block -or at least considerably water-down - the 2004 pension reform proposal set forth by the PRI and the PAN. These three explanatory variables are: the profound and lasting divisions between CT-affiliated unions and independent labor organizations; the lack of popular support for independent labor's discourse and policy orientation in the context of the reform of the IMSS; and dissentions between independent unions themselves.

Findings indicate firstly that organized labor was divided from the very beginning of the 2004 pension reform process. On the one side, the CT's leadership claimed the paternity of the reform proposal. The Labor Congress publicly supported this project by adopting the discourse of PRI and PAN Congresspersons, which affirmed that the greater good of 45 million insured members was threatened by the privileges of a few: the IMSS workers and retirees. On the other hand, the SNTSS and the independent union confederations vehemently opposed this reform, which they depicted as a frontal attack on the remaining elements of the public pension system of Mexico, on the SNTSS and independent unionism, and on constitutionally guaranteed labor rights. This profound division between the two main tendencies of labor organizations most likely had a significant negative impact on the capabilities of the SNTSS and its allies to successfully pressure policy makers in order for them to reject the reform proposal.

Indeed, the CT held that its position was in defense of the welfare and interests of the 12 million workers contributing to the IMSS and of their families, who benefited from the Institute's services. CT leaders added that they did not support the UNT's decision to call for a general strike, arguing that such action would only hurt the general population while defending the benefits of a few privileged workers (Pensamiento \& Guerrero 2004). In a revealing statement, Leonardo Rodríguez Alcaine -“spiritual leader” of the CT and Secretary General of one of its most important member unions-claimed that only he had the power to paralyze Mexico, hence suggesting that independent unions lacked the membership and coordination necessary to lead a successful general strike (Muñoz Rios 2004). Further to this, José Ramírez Gamero, one of the leaders and spokesperson of the CT, indicated that the UNT and FSM -the two main independent union confederations-were not involved in the representation of the millions of workers who were most affected by the poor quality of the IMSS' workers, resulting from the Institute's financial difficulties. Ramírez added that independent labor confederations were protecting only the narrow and egotistical interests of a small minority of workers, whereas the CT was defending and furthering the wellbeing of the majority of Mexican workers (Private interview, August 2004).

On the other side, in addition to holding a discourse denouncing the perils and shortcomings of the proposed pension reform, the SNTSS and its allies exerted pressure on policy makers in the hope that these would in turn reject that project. Since the SNTSS was no longer a member of the CT, it therefore escaped the direct control of the Labor Congress's leadership as well as that of the PRI during the 2004 pension reform process. Likewise, the SNTSS did not participate in any formal corporatist system of interest representation linking it to the federal government -as was the case during the 1995 reform - which could have prevented it from engaging in active resistance to the reform proposal. The SNTSS and its independent union partners therefore utilized a variety of 
methods to impede -and later protest - the adoption of the pension reform by the Congress.

As such, independent labor staged marches and demonstrations throughout July and August. The independent unions' threat to engage in walkouts was also carried out, but not before Congress had already promulgated the reform bill. Indeed, the SNTSS and its allies resorted to two days of intermittent work stoppages, on 31 August and 1 September, in reaction to Congress' promulgation of the reform. However, independent labor organizations could not initiate long-term strike activities without previously obtaining the permission of the federal Labor Tribunal. This provision of the Federal Labor Law demanded more time than what was available to independent unions and limited their possibilities of resorting to a widespread and sustained movement of strikes. Although these actions of protest did have some impact on the population and economic activity of Mexico, they did not paralyze the nation. In fact, the functioning of the IMSS, as well as that of the electricity and telecommunication industries -the strategic sectors of the economy where the main unions allied with the SNTSS were present-was essentially not affected by these measures (Martínez et al. 2004).

In adopting a public stance according to which the CT was acting to defend the interests of 12 million workers and of 45 million beneficiaries linked to the IMSS, the Labor Congress sought to destroy the legitimacy of the arguments set forth by the SNTSS and its independent labor allies. Indeed, the Labor Congress' discourse made it impossible for independent union confederations to claim that they were speaking in the name, and acting for the greater good, of Mexico's labor force taken as a whole. As such, the CT's rhetoric put the SNTSS and its allies on the defensive. Independent unions would ultimately be unable to extricate themselves from that position, and were unsuccessful in mobilizing the citizenry's support to its efforts.

Available information indicates that the general public was rather receptive to the discourse of the reform proponents and did not seem to share the concerns of opponents to that project. Indeed, a national poll conducted on 31 July -i.e. immediately after the reform had been approved by the Lower House of Congress, but just before Senate voted on it-revealed that an overwhelming majority (84\%) of the interviewed citizenry believed that there was a crisis afoot in the IMSS. Furthermore, $67 \%$ of respondents considered that it was imperative to reform the legal framework regulating the Institute's functioning. Perhaps most importantly, 53\% of the interviewees supported the PRI-PAN reform project, while 38\% manifested their disapproval of it. Also, respondents expressed a negative evaluation of the quality of the medical services offered by the IMSS, by attributing it a "failing average grade" of 4.6 out of 10 . Nonetheless, $71 \%$ of the interviewees expressed their support for a system of public health care services, such as the one provided by the IMSS (Reforma 2004b).

This data suggests that the arguments of the SNTSS and its allies did not convince the majority of the Mexican population, which seems to be more concerned with the IMSS' financial solvability as well as the inadequacy of the health care services it offers. In addition, the prevailing public attitude may have been significantly determined by the relatively restricted scope of the 2004 reform. Indeed, the 1995 pension changes affected over 10 million private sector workers involved in very diverse types of economic activity. In that case, the impact of the reform was felt across economic sectors and degrees of workers specialization. The 2004 reform, by contrast, only affected 
immediately 370,000 workers and 120,000 retirees, all specifically linked to IMSS. This may have helped the cause of reform proponents, by fostering among the general population a sense that IMSS workers and retirees were indeed overly-privileged in their working and retiring conditions, to the detriment of the rest of the citizenry's basic health-related interests.

In addition to these persisting divisions between the CT and independent unions, it seems that the independent labor movement experienced stress and discord within its own ranks during and after the reform process. This is likely to have affected the scope and efficiency of their mobilization efforts. These tensions between independent labor organizations appeared quite clearly in the interviews we conducted in Mexico during the months of August and September 2004 with leaders of eight foremost independent unions. The majority of these respondents observed that independent unions had lacked unity and political will during their campaign of opposition to the pension reform proposal. They generally considered that this was a central cause for independent labor's failure to force the PRI and the Fox government to modify the proposed pension reform, or to significantly modify it.

Among others, Alejandra Barrales, leader of the Asociación Sindical de Sobrecargos de Aviación de México (Union of Ground Personnel of Mexican Airports, ASSA) and PRD Deputy in the Federal District Legislature, explained that independent labor's very clear lack of effectiveness in mobilizing its members and civil society, and its lack of success in stopping or significantly modifying the reform, negatively affected public confidence in these unions. Barrales added that independent labor's political ineffectiveness was attributable to its leaders' lack of confidence in the strength of the labor movement as well as poor political strategizing. She considered that, as such, the dynamics surrounding the 2004 pension reform represented a considerable defeat for independent unionism as a whole. Agustín Rodríguez Fuentes, Secretary-General of the Sindicato de Trabajadores de la Universidad Nacional Autónoma de México (Union of Workers of the National Autonomous University of Mexico, STUNAM) and federal PRD Deputy believed that the SNTSS did not react in a timely and forceful fashion to the 2004 reform proposal, which derailed the subsequent efforts of its independent labor allies.

In fact, many interviewees blamed SNTSS Secretary-General Galina Vega for the independent unions' failures in the 2004 pension reform process. For instance, Sergio Sánchez, Secretary of Communications and spokesperson for the Sindicato Mexicano de Electricistas (Mexican Union of Electricians, SME) accused Vega Galina of collusion with the IMSS and PRI authorities, underlining the fact that Vega Galina was himself a PRI Federal Deputy at the time of the reform, and that he was unwilling to distance himself from that party even after the proposal was introduced to and strongly supported by that party in Congress. Sánchez indicated that, as a result, the SNTSS could not mobilize in a forceful and efficient fashion. Rodolfo Pérez Ruiz, Secretary-General of the Sindicato de los Trabajadores de la Universidad Autónoma Metropolitana (Union of Workers of the Autonomous Metropolitan University, SITUAM) added that Vega Galina was predisposed to accept the 2004 reform proposal since he had already reached a secret collective contract agreement with IMSS administrators months before that, which contained similar provisions regarding the pension scheme of the Institute's employees. Nevertheless, the interviewee indicated that members of Vega Galina's union forced him to change his views and to launch a movement of resistance to the project during the 
summer of 2004. Still, Pérez affirmed that Vega Galina never really wanted to fight this reform, which significantly hampered the efforts of the SNTSS and its allies as this created problems of cohesion and organization.

It should be noted here that the unions of both Sánchez and Pérez were members of the FSM rather than of the UNT, and that Vega Galina was co-president of the UNT during 2004. Although there have been no serious conflicts between these two independent labor confederations since their relatively recent foundation, ${ }^{8}$ this fact may explain to some extent these respondents' greater willingness to target more specifically Vega Galina as a central guilty party for the ineffectiveness of the independent labor movement in preventing the ratification of the 2004 pension reform.

For his part, SNTSS Secretary-General Vega Galina claimed that his union as well as its allies could not stop the reform process because both president Fox and the PRI had a deep need to prove to the citizenry that they could enact significant reforms, in the perspective of the 2006 elections. Vega Galina considered that, although Fox is not eligible for reelection, he would like to be remembered as being responsible for important policy reforms, a legacy that could also help his party in future electoral contests. What is more, the interviewee affirmed that the PRI was on a quest to prove that it was capable of governing in a democratic context, and that it was the only true political force in Mexico. As a result, Vega Galina said that the PRI as well as the Fox government and the PAN fraction in Congress were unflinching in their support of the proposal, which they imposed despite opposition from significant segments of society. Eduardo Torres, Press Secretary for the powerful Sindicato de Telefonistas de la República Mexicana (Union of Telephone Workers of the Mexican Republic, STRM), supported this line of argumentation during our interview, arguing furthermore that the PRI and the PAN had passed a de facto political accord that left little room for negotiation and flexibility in the matter of the IMSS’ pension system reform.

\section{Conclusion}

Both the 1995 as well as the 2004 rounds of changes to the structure and functioning of the IMSS constitute important pension reforms. The 1995 restructuring package deeply transformed the nature of pension systems for private sector workers in Mexico, by privatizing the IMSS' pension scheme. Although not as immediately far reaching in financial terms, the 2004 reform still holds great sociopolitical and theoretical significance. Indeed, this reform was enacted and implemented in the context of a democratic regime; it threatened well-defined entrenched interests; and it opened the door to further reforms of the remaining public pension plans -in particular that ran by the ISSSTE.

In that perspective, the results of our investigation tend to contradict some dominant assumptions in the existing literature on pension reforms in Latin America. This body of research assumes, among other things, that major pension reforms such as those which occurred in 1995 and 2004 in Mexico are facilitated by the presence of an authoritarian regime, and much less likely under democratic rule. This is attributable to the often considerable political costs of these reforms for the party in power, and to the enhanced abilities of social actors - and especially unions - to resist these projects in a democratic context. By contrast, our paper has found that Mexico's regime transition to

\footnotetext{
${ }^{8}$ The UNT was founded in November 1997, and the FSM in August 1998.
} 
democracy seems to have changed very little with regards to labor's capacity to block important pension reforms. Indeed, our findings suggest that the democratic transition in Mexico did not significantly improve the capability of the SNTSS and its labor allies to resist important socioeconomic reforms set forth by the government or Congress. We have identified three factors leading to this result: the lack of popular support for independent labor's discourse and policy orientation in the context of the reform of the IMSS; the profound and lasting divisions between CT-affiliated unions and independent labor organizations; and dissentions between independent unions themselves.

To be sure, the 1995 reform targeted the pension schemes of 10 million workers active in the various segments of the private sector. By contrast, the 2004 reform impacted 370,000 public sector workers, all employed by the IMSS. This characteristic may account in part for the general public's lack of responsiveness to the discourse of the 2004 reform opponents, as a lot less people expected to be affected negatively by this reform than in 1995. In fact, if anything, the results of the only major opinion poll conducted on this theme at the time of the reform show that citizens were in their majority supportive of this project, as they anticipated that the IMSS' services would be improved as a result of those changes.

Our findings tend to refute some key assumptions of the preexisting literature, and in particular Mesa-Lago and Müller's (2002, p. 706) assertion that "there is an inverse relationship between the degree of democratization and that of privatization" of pension schemes, i.e. "the less democratic a regime at the time of the reform, the more it will downsize the public pension system”. In the case of Mexico, a significant reform towards pension privatization occurred in 2004 despite the country's transition to democracy in 2000. It is also noteworthy that Mesa-Lago and Müller's secondary explaining variables do not seem to account for the Mexican case either. Among other things, the Presidency did not enjoy a high degree of control over Congress; Mexico had experienced its last economic crisis in 1995, and it had been several years already since the country recuperated from it by the time of the 2004 reform; external creditor agencies -such as the International Monetary Fund and the World Bank-had asked for such as measure to be taken, but had not overly pressured the Mexican government regarding it; and the Mexican Constitution does establish social security as a responsibility of the state, but the government and Congress interpreted this provision as further legitimization of their effort to reform the IMSS employees' pension system. As such, all these traits of the 2004 IMSS reform run counter to the predictions of Mesa-Lago and Müller.

Also, the formal termination of the corporatist system in 2000 does not appear to have affected in a significant and positive manner the political influence of independent unions and their ability to defend and promote the interests of their membership. In particular, our findings highlight the continuation of divisions between labor organizations during the 2004 pension reform in Mexico. The opposition to the 2004 reform was comprised in great part by independent labor organizations, which only represented 1.5 million workers. By comparison, the membership of ex-official unions, confederated under the CT, hovered around 6 million workers. Since the CT clearly came out in favor of the 2004 reform, this limited the ability of independent unions to mobilize sections of the labor force which lay outside of their membership, in support of their political action. Indeed, the Labor Congress and its constituent unions aligned themselves with the policy position espoused by the PRI, and rejected the independent union 
confederations' repeated calls for unity, as CT leaders openly supported the PRI-PAN reform proposal. This suggests that the corporatist framework may have continued to be relatively functional in post-transitional Mexico. Our findings also suggest that divisions within independent labor organizations have negatively affected the coordination of the movement's political actions and its mobilization and organizational capabilities.

In retrospect, it seems unlikely, that the 2004 reform represented the "most significant attack on independent unionism in decades", or that it sought to destroy the SNTSS, as argued by some analysts and by opponents of changes to the IMSS workers' pension plan (MLNA 2004, July). To be sure, 2004 was a year of contract renegotiation for the IMSS and its employees. It is therefore plausible that the emphasis put by the IMSS on the problems generated by its workers' pension plan was utilized as a means of pressuring the SNTSS into accepting certain contractual provisions that the union originally rejected, such as the reforming of the Institute employees' pension regime. As such, if anything, the 2004 reform represented a deviation from the provisions guiding collective negotiations as indicated in Constitutional Article 123 as well as in the Federal Labor Law, and which reject the involvement or interference of a third party in employeremployee negotiations. Nevertheless, this would not be the first violation to these legal provisions in the past two decades, as the Mexican federal government has carried on with a clear policy of de facto labor flexibilization in order to keep real salaries low, so as to increase the competitiveness of Mexican industries on the world market (De la Garza 1998).

It should be noted in closing that the 2004 pension reform did not change much in the short to medium term, as the new provisions will truly impact the IMSS' financial situation in roughly 30 years, i.e. when new workers hired under the new retirement scheme begin to retire. In the meantime, the Institute's pension system will likely still have to utilize resources from the worker-employer contributions in order to pay for the IMSS' workers who retired under the previous pension plan. Hence, another reform is to be expected before long. It remains to be seen whether, at a minimum, independent unions will be more effective in their mobilization strategy then, and if they can convince CT-linked unions to join them in creating a united organized labor front at that time. In the current context, the former scenario seems likely, but the latter remains quite improbable.

\section{Bibliography}

-Acuña, Rodrigo R. and Augusto Iglesias. 2001. "Chile’s Pension Reform after 20 Years”. Social Protection Discussion Paper, Human Development Network: IBRD, No. 0129.

-Alcalde, Arturo. 2003. "Reforma laboral: una iniciativa para favorecer al corporativismo" in Arturo Alcalde et al. Reforma Laboral. Mexico City: Universidad Nacional Autónoma de México, pp. 15-40.

- . 2004. "IMSS - Una iniciativa lamentable”, in La Jornada, 16 July. $\mathrm{ly}=1)$

-Arvizu Treviño, Sergio. 2002. Mexican Pension Reform and Risk Management Framework. Paper presented at the 2002 Conference of the International Social Security Association (Moscow). 
(http://www.issa.int/engl/reunion/2002/Moscou/2reports.htm)

-Becerril, Andrea. 2004. "Los tecnócratas se impusieron a los nacionalistas, tras 5 horas de debate”, in La Jornada, 6 August. (www.jornada.unam.mx/007n4pol/)

-Betrones Rivera, Manlio Fabio. 2004. Proyecto de decreto que reforma los articulos 277 D y 286 K de la Ley del Seguro Social”. Mimeo. Cámara de Diputados. (www.diputados.gob.mx/comisiones59legislatura/seguridad_social/docts/proyect o_decreto.pdf)

-Borzutzky, Sylvia. 1998. “Chilean Democracy before and after Pinochet”. In James M. Malloy and Kurt von Mettenheim, eds., Deepening Democracy in Latin America. Pittsburgh: University of Pittsburgh Press.

-Bellin, Eva. 2000. "Contingent Democrats; Industrialists, Labour and Democratization in Late-Developing Countries”. World Politics, Vol. 52 (January), pp. 175-205.

-Berins Collier, Ruth. 1992. The Contradictory Alliance State-Labour Relations and Regime Change in Mexico. Berkeley: University of California, International and Area Studies.

-Burgess, Katrina. 1999. “Loyalty Dilemmas and Market Reform; Party-Union Alliances under Stress in Mexico, Spain and Venezuela” World Politics, Vol. 52 (October), pp.105-134.

-Carstens, Agustin G. 1997. “The Reform of Social Security in Mexico” Conference Series [Proceedings], June. Boston: Federal Reserve Bank of Boston, pp. 153156.

-Caulfield, Norman. 1998. Mexican Workers and the State. Fort Worth: Texas Christian University Press.

-Cavallos, Diego. 2004. "Mexico: Social Security Workers Fight Even 'Bandaid' Reform”, 5 August. Re-published in Choike

(www.choike.org/nuevo_eng/informes/2218.html)

-Cerda, Luis. 1996. The Mexican Pension Reform. Consultative paper prepared for the Secretaría de Hacienda y Crédito Público.

-De la Garza, Enrique. 1991. "Independent Trade Unionism in Mexico: Past Developments and Future Perspectives" in Kevin J. Middlebrook, ed. Unions, Workers, and the State. San Diego: University of California, Center for U.S.Mexican Studies, pp. 153-184.

1994. "The Restructuring of State-Labour Relations in Mexico" in Cook, Maria Lorena, Kevin Middlebrook and Juan Molinar Horcasitas, eds., The Politics of Economic Restructuring: State-Society Relations and Regime Change in Mexico. San Diego; the Center for US-Mexican Studies, University of California, pp. 195-217.

-__ _ 1998 "Sindicatos, Estado y economía en México" in Konrad Adenauer Stiftung, ed. El sindicalismo ante los procesos de cambio económico y social en América Latina. Buenos Aires: Grancharoff S.A., pp. 183237.

-Espinosa-Vega, Marco A., and Tapen Sinha. 2000. “A Primer and Assessment of Social Security Reform in Mexico”. Federal Reserve Bank of Atlanta Economic Review, Vol. 1.

-Grayson, George. 1989. The Mexican Labour Machine: Power, Politics and Patronage. Washington DC: CSIS. 
-Guerrero, Claudia, et al. 2004. “Aprueban reforma del IMSS” in Mural, 30 July. (www.mural.com/nacional/articulo/431153/))

-Haggard, Stephan. 1992. “Democracy and Economic Growth: What Relation?” in Daniel Schydlowsky and James Weaver, eds., Structural Adjustment: Retrospect and Prospect. New York: Praeger.

-Haggard, Stefan and Robert R. Kaufman. 1992. The Politics of Economic Adjustment. Princeton: Princeton University Press. 1995. The Political Economy of Democratic Transitions. Princeton; Princeton University Press.

-Heredia, Blanca. 2001. Clientelism in Flux: Democratization and Interest Intermediation in Contemporary Mexico. Working Paper. Mexico City: CIDE.

-Huber, Evelyn, and John D. Stephens. 2000. “The Political Economic of Pension Reform: Latin America in Comparative Perspective”. Occasional Paper 7, edited by UNRISD.

-Instituto Mexicano del Seguro Social (IMSS). 2001. Memoria Estadística 2001. (http://www.imss.gob.mx/IMSS/IMSS_SITIOS/DPF/DPF_DIF/estadisticas/mem oria/2001/)

___ 2003. Informe al Ejecutivo Federal y al Congreso de la Unión sobre la Situación Financiera y los Riesgos del Instituto Mexicano del Seguro Social. (http://www.imss.gob.mx/IMSS/IMSS_INF/)

-_ 2004. Informe al Ejecutivo sobre la Situación Financiera del IMSS. (http://www.imss.gob.mx/IMSS/IMSS_INF/)

-Instituto Nacional de Estadística, Geografía, e Informática (INEGI). 2005. Estadísticas Sociodemográficas: Seguridad Social. (http://www.inegi.gob.mx/est/default.asp?c=1872)

-Kaufman, Robert R. 1985. "Democratic and authoritarian responses to the debt issue: Argentina, Brazil, Mexico.” International Organization, Vol. 39, No. 3.

-Madrid, Raul L. 2003. "Labouring against Neoliberalism: Unions and Patterns of Reform in Latin America”. Journal of Latin American Studies, Vol. 35, pp. 53-88.

-Martínez, Fabiola, et al. 2004. “Un éxito, la suspensión de actividades: líderes”, in $L a$ Jornada, 2 September.

(www.jornada.unam.mx/2004/sep04/040902/011n2pol.php?origen=index.html\&fl $\mathrm{y}=1)$

-Mayer, Jean F. 2005. “The Mexican Federal Labour Law Reform Process, 2001-2003”, in LABOUR, Capital and Society, Vol. 36, No. 1.

-Mendez, Enrique. 2004. "Pujan PRI y PAN para aprobar fast track la reforma al Seguro Social”. La Jornada, 20 July. (www.jornada.unam.mx/007n4pol.php)

-Mesa-Lago, Carmelo, and Katharina Müller. 2002. "The Politics of Pension Reform in Latin America”. Journal of Latin American Studies, Vol. 34, pp. 687-715.

-Mexican Labour News and Analysis (MLNA). Various years and issues. (http://www.ueinternational.org/)

-Middlebrook, Kevin J. 1995. The Paradox of Revolution: Labour, the State, and Authoritarianism in Mexico. Baltimore: The Johns Hopkins University Press.

-Muñoz Rios, Patricia. 2004. "Sólo yo puedo bajar el switch en el país, asegura Rodríguez Alcaine”, in La Jornada, 10 August. (www.jornada.unam.mx/2004/ago04/040810/014n1pol.php?origen=index.html\&f 
$\mathrm{ly}=1)$

-Murillo, Victoria. 2000. "From Populism to Neoliberalism: Labour Unions and Market Reforms in Latin America”. World Politics, Vol. 52 (January), pp. 135-174. . 2001. Labor Unions, Partisan Coalitions, and Market Reforms in Latin America. Cambridge; Cambridge University Press, Comparative Politics Series.

-Nuñez, Ernesto. 2004. "Proponen candados en el IMSS”, in Mural, 14 July. (www.mural.com/nacional/articulo/398115/) 2004b. "Impulsa 'sector obrero' reforma al IMSS”, in Mural, 15 July. (www.mural.com/nacional/articulo/398368)

-Orihuela, Gabriel and Wendy Selene Pérez. 2004. "Critica Fox privilegios en el IMSS”, in Reforma, 28 July. (www.mural.com/nacional/articulo/402904)

-Patroni, Viviana. 1998. "The Politics of Labour Legislation Reform in Mexico." Capital \& Class , Vol. 5, pp. 107-132. . 2001. "The Decline and Fall of Corporatism? Labour Legislation Reform in Mexico and Argentina during the 1990s.” Canadian Journal of Political Science, Vol. 34, No. 2, pp. 249-274.

-Pensamiento, Daniel and Claudia Guerrero. 2004. "Rechazan ir a huelga por reforma a IMSS”, in Mural, 16 July. (www.mural.com/nacional/articulo/398778/)

-Reforma. 2003. “Crecen Costos por Pensiones”, re-published in Impuestum, 19 June. (http://www.impuestum.com/noticias/1922.html)

-Reforma. 2004a. "Pasa en comisiones reforma del IMSS”, 20 July. (www.mural.com/nacional/articulo/399946/)

-Reforma. 2004b. “Reprueban al IMSS”, 4 August, p. 6.

-Reyes Frausto, Sandra. 2000. Population Ageing in the Mexican Institute of Social Security: Health Policy and Economic Implications. Mexico City: Fundación Mexicana Para la Salud A.C.

-Salazar, Claudia et al. 2004. “Aprueba Senado reformas al IMSS”, in Mural, 5 August. (www.mural.com/nacional/articulo/405246/)

-Santos Azuela, Hector. 1989. “La libertad sindical en México” in Graciela Bensusán and Carlos García (Eds.) Modernidad y legislación laboral. Mexico; FES Editors.

-Schmitter, Philip. 1974 "Still the Century of Corporatism?” The Review of Politics, Vol. 36, No. 1, pp. 85-131.

-Teichman, Judith. 1996. "Economic Restructuring, State-Labour Relations, and the Transformation of Mexican Corporatism,” in Gerardo Otero, ed. Neoliberalism Revisited: Economic Restructuring and Mexico's Political Future. Boulder: Westview Press, pp. 149-166.

-Unión Nacional de Trabajadores (UNT). 2004. “Pronunciamiento de los trabajadores ante la ofensiva gubernamental y patronal contra los derechos contractuales y el régimen de jubilaciones y pensiones”. Mimeo.

(www.strm.org.mx/politica/despl2307.htm)

-Zapata, Francisco. 1995. El sindicalismo mexicano frente a la reestructuración. Mexico City: El Colegio de México. 